\title{
Contribuições da estética à ação pedagógica na EJA: ressonâncias formativas na escola e na universidade
}

\author{
Contributions of the aesthetics to the pedagogical action in \\ Adult Education: formative resonances at school and university
}

Clarissa HAAS ${ }^{1}$

Karine STORCK²

\begin{abstract}
Resumo
O estudo analisa a ação pedagógica na Educação de Jovens e Adultos (EJA) sob a ótica de seus demandantes e de estudantes universitários em formação para a docência. Por meio de pesquisa participante e com foco nas contribuiçóes da estética e de suas relaçóes com o campo da ética, a articulação entre os saberes da universidade e da escola possibilitou a reflexão sobre desafios atuais enfrentados na EJA: a infrequência, a evasão escolar e a juvenilizaçáo de seu público. Além disso, tal articulação propôs o olhar à diversidade e aos cotidianos como elemento enriquecedor da ação pedagógica.
\end{abstract}

Palavras-chave: Educação de Jovens e Adultos (EJA). Estética. Formação Docente. Ação Pedagógica.
Abstract

The study examines the pedagogical action in the Youth and Adult Education (EJA) from the perspective of their applicants and university students in training for teaching. Through participatory research and focusing on the contributions of the aesthetics and their relationship to the field of ethics, the relationship between the knowledge of university and high school institutions enabled the reflection on current challenges faced by EJA: the infrequency, school dropout and the juvenilization of its audience. Furthermore, this joint proposes a look for diversity and the everyday as an enriching element of the pedagogical action.

Keywords: Education for Youth and Adults (EJA). Aesthetics. Teacher Training. Pedagogical Action.

1 Doutora em Educação pela Universidade Federal do Rio Grande do Sul - UFRGS (2016). Professora da área de Pedagogia do Instituto Federal de Educaçáo, Ciência e Tecnologia do Rio Grande do Sul (IFRS). Integrante do Núcleo de Estudos em Políticas de Inclusão Escolar da Universidade Federal do Rio Grande do Sul (NEPIE-UFRGS). Endereço profissional: IFRS - Campus Caxias do Sul. Rua Avelino Antônio de Souza, 1730. Bairro Nossa Senhora de Fátima, Caxias do Sul. CEP: 95043-700. Tel.: (54) 3204-2100. E-mail: <cla.haas@hotmail.com>.

2 Mestra em Educação pela Universidade Federal do Rio Grande do Sul - UFRGS (2015). Professora de Artes Visuais do Colégio de Aplicação da UFRGS. Integrante do ARTEVERSA - Grupo de estudo e pesquisa em arte e docência (UFRGS). Endereço profissional: Universidade Federal do Rio Grande do Sul, Colégio de Aplicação. Campus do Vale. Av. Bento Gonçalves, 9500. Bairro Agronomia. CEP: 91509-900. Porto Alegre, RS - Brasil. Tel: (51) 3308-6976. E-mail: <karinestorck@gmail.com>.

R. Educ. Públ. v. 27 n. 66 p. $793-812$ set./dez. 2018 


\section{Apresentando os propósitos do estudo}

Abrimos o presente estudo com uma citação de Soares (2008), que, em nosso ponto de vista, sintetiza, em grande medida, a intencionalidade desta investigação. Conforme o autor mencionado, são perspectivas atuais das pesquisas e das práticas pedagógicas da área da Educação de Jovens e Adultos (EJA):

Hoje, a EJA, seja no âmbito das práticas, seja no âmbito da sua sistematização teórico-metodológica tem priorizado algumas temáticas em suas discussôes, que podem ser concebidas como desdobramentos daquelas que se observavam nas décadas anteriores: necessidade de se estabelecer um perfil mais aprofundado do aluno, a tomada da realidade que está inserido como ponto de partida das açóes pedagógicas, o repensar dos currículos com metodologias e materiais didáticos adequados às suas necessidades e a formação de professores condizente com a especificidade da EJA são algumas delas. (SOARES, 2008, p. 202).

Portanto, pretendemos aliar-nos às necessidades atuais de investigação da área comentadas por Soares (2008), assumindo como desafio o diálogo entre a formação inicial docente no âmbito da universidade com as práticas pedagógicas da/para EJA protagonizadas na escola de educação básica.

Além disso, buscamos articular uma reflexão que, do modo como propõe Arroyo (2011), ambiciona reconfigurar a história da EJA como campo histórico e político, reconhecendo na diversidade de suas propostas pedagógicas e na especificidade cultural das trajetórias de seus demandantes o potencial criador e inovador da área, ao invés de reproduzir o discurso dominante da diversidade como estopim para propostas pedagógicas indefinidas e desencontradas ao longo da história da modalidade. Desse modo, assumimos como pressuposto que as políticas públicas, no caso específico, a política pública da EJA, têm seu protagonismo e sua possibilidade de reinvençáo em cada microespaço pela atuação de seus atores do cotidiano: estudantes, professores da EJA e demais profissionais da educação.

Para isso, a metodologia de cunho participante analisa e relaciona as narrativas dos saberes profissionais das autoras, uma vez que, no momento de elaboraçáo desta investigação, estiveram inseridas no contexto profissional, como professora do ensino superior da disciplina de Educação de Adultos: História e Política, em uma Instituição de Educação Superior (IES), e professora da modalidade EJA, em uma Instituição Escolar de Educação Básica, ambas atuando na instância administrativa pública. 
O diálogo com essas narrativas é tecido por meio do pensamento de Larrosa acerca da experiência como campo formativo. Desse modo, formar-se estudante na EJA, formar-se professor da EJA é abordado neste estudo a partir das contribuições do campo da estética e de suas relaçóes com a ética, ampliando a concepção de formação ao que, segundo Larrosa (2002), requer uma viagem ou aventura para o interior de si mesmo.

O processo de formação está pensado, melhor dizendo, como uma aventura. E uma aventura é, justamente, uma viagem no não planejado e não traçado antecipadamente, uma viagem aberta, em que pode acontecer qualquer coisa, e na qual não se sabe onde se vai chegar, nem mesmo se vai se chegar a algum lugar. De fato, a idéia da experiência formativa, essa idéia que implica um se voltar para si mesmo, uma relação interior com a matéria de estudo, contém, em alemão, a idéia de viagem. Experiência (Erfahrung) é, justamente, o que se passa numa viagem (fahren), o que acontece numa viagem. E a experiência formativa seria, então, o que acontece numa viagem e que tem a suficiente força para que alguém se volte para si mesmo, para que a viagem seja uma viagem interior. (LARROSA, 2002, p. $52-$ 53 , grifos do autor).

Nesse sentido, destacam-se distintos papéis ou personagens em viagem formativa: os jovens estudantes da modalidade EJA - totalidades finais do ensino fundamental; os estudantes de distintas licenciaturas, que estáo buscando formação para a atuação futura como professores da EJA; a professora da disciplina de artes visuais na EJA - totalidades finais do Ensino Fundamental e a professora da Educação Superior, ambas em formação continuada permanente voltada ao cotidiano escolar e às especificidades dos sujeitos em escolarização nos bancos escolares e acadêmicos, como espaço de invenção e (re)criação de sua docência.

Portanto, o texto está estruturado a partir das cenas ou imagens evocadoras da EJA e a ação pedagógica em artes visuais e da EJA e a formação inicial docente para a docência. A compreensão de que a disciplina de artes deva propiciar o entrelaçamento entre educação e cultura, por meio do campo da estética (MEIRA, 2001), constituiu-se como o elo integrador das cenas, delineando o itinerário teórico-metodológico.

Desse modo, buscou-se confrontar a narrativa coletiva e determinante das representaçôes sociais a respeito da EJA quanto à infrequência e à evasão de seus estudantes, por meio de uma situação pedagógica proposta na disciplina de artes 
visuais aos alunos dessa modalidade de ensino. Nessa ocasião, a narrativa visual, a leitura, releitura e produção de imagens estiveram em foco, com o objetivo de promover a construção de conhecimento acerca das dificuldades vivenciadas no cotidiano escolar, considerando as dimensóes estética e ética presentes nesse ato como aspectos indissociáveis.

Para pensar na relação entre ética e estética possível no processo formativo el ou educativo nos interessa a visão de Hermann, quando diz que:

As possibilidades da estética parecem, entâo, constituir uma forma produtiva de compreender as novas exigências éticas diante da pluralidade, na medida em que permitem transcender as fronteiras unilateralmente racionais da interpretação iluminista do projeto educacional. A estruturação estética da educação pode ampliar de forma significativa a consciência ética, liberando novas formas de sensibilidade que temos deixado de lado. (HERMANN, 2005, p. 31).

Ainda sobre a relação do campo estético com a educação, conforme Meira (2001), a educação como campo fértil para desencadeamento da experiência estética ampara-se na realidade cotidiana, ao mesmo tempo em que traz para as indagaçóes teóricas a complexidade do mundo da vida, porque faz o trânsito da ida e da volta entre o discurso e a prática, revelando como se constitui o imaginário e a percepção dos homens nas suas visôes de mundo. A autora aponta a necessidade de que as relaçóes com o campo da estética, possibilitadas por meio da disciplina de artes visuais, tenham caráter interdisciplinar. Assim, a estética, como campo de conhecimento, assume o desafio de permear o currículo, para mais além de estar vinculada a uma disciplina escolar.

A estética permite reconhecer o estranho como parte do processo formativo; não segue padrão ou receita; possibilita a criação da própria formação de si mesmo, proporcionando formas de conhecimento avessas ao racionalismo e que considerem as diferenças e a heterogeneidade do mundo cotidiano como experiências criadoras da sensibilização.

Entendemos que os conhecimentos construídos por meio da estética podem ser associados ao ato de ler o mundo, em Freire (1989), logo, como uma condução política e de exercício da cidadania que reposiciona o sujeito criticamente em sua condição histórica. Ler o mundo ou, em sentido estrito, ler a palavramundo, para Freire (1989), é um ato de transformação social. Com a velocidade atual que a sociedade produz informaçóes, principalmente 
de cunho visual, entendemos necessário incorporar às premissas de Freire que ler o mundo é ler a palavramundo e, igualmente, as imagensmundo. $\mathrm{Ou}$ seja, o ato de ler deve ser traduzido como compreensão e interpretação das distintas linguagens que operam os sistemas simbólicos de representação da atualidade, no qual a imagem, como sistema de pensamento, opera como um processo basilar na formação do coletivo social.

Por isso é que falar em pensamento estético é imprescindível para pensar educação, nos tempos atuais, sobretudo porque saber, hoje, é ter acesso a formas de interação e conhecimento que demandam visibilidade complexa, sendo extremamente complexa a realidade em que vivemos e convivemos. (MEIRA, 2001, p. 101).

\title{
2 Imagens da EJA: a ação pedagógica em artes visuais
}

\author{
"Vão fechar a EJA!" \\ "Vão fechar a escola!?!"
}

"Sôra, é sério que vão fechar a EJA?"

(Fala de estudantes da EJA de uma escola pública na cidade de Porto AlegreRS, durante o início de uma aula de artes visuais).

Iniciamos esta seção mencionando as expressóes dos alunos que, além de pôr em destaque um dos desafios políticos, na atualidade, da modalidade de ensino (relativo à iminência da não garantia da oferta das turmas nos estabelecimentos escolares públicos mediante a pouca frequência e a evasão dos seus demandantes), foi geradora da proposta que originou as imagens, ponto de partida para que esta escrita fosse pensada.

Antes de apresentar as produçóes propriamente, é importante saber sobre o contexto de decorrência de tais falas. Entáo, explicamos: uma proposta um tanto descontextualizada foi lançada aos alunos, envolvendo a apresentaçáo de uma peça teatral na escola. A atividade teria o custo de R \$ 5,00 e ocorreria em horário de aula, portanto, todos estavam convidados, ou melhor, convocados a participar. Os professores também foram avisados, sem antes haver algum planejamento relativo à atividade, solicitação de tal demanda ou discussão no grupo docente e/ou com os discentes.

O ocorrido foi que, chegado o dia, nenhum aluno se propôs a participar da atividade. A professora responsável pela disciplina de artes visuais não estava presente nessa data, mas no dia seguinte, no início do período de 
aula, ouvia os burburinhos: "Vão fechar a EJA!"; "Vão fechar a escola!?!"; "Sôra, é sério que vão fechar a EJA?" Conversando um pouco com os alunos e colegas professores, a fim de inteirar-se do fato ocorrido que causou esses comentários, soube que isso teria sido dito em razão da não participação dos alunos na atividade proposta. A professora, entáo, questionou os alunos quanto ao motivo da não participação: "Seria um boicote? Ou o custo do ingresso?" Eles imediatamente disseram que náo era nada disso. Aparentemente, foi pelo desinteresse mesmo, traduzido na fala de uma aluna: "Ah sôra! Nada a ver isso aî?"

A professora, inquieta com os comentários e a situação que se vivia ali, não conseguiu prosseguir a aula conforme o planejamento inicial. Acreditava que isso também fazia parte da aula e que, com o fato ou a partir dele, poderia dar novo formato às atividades da disciplina. Ainda para ordem de contextualização, o que estava sendo desenvolvido nas aulas era um projeto que envolvia atividades e experiências relativas a narrativas presentes na cultura visual $^{3}$, para posterior discussão dessas na arte contemporânea. Após o episódio desse dia, o projeto ganhou novo rumo.

Diante da situaçáo, a professora propôs que os alunos criassem, a partir dessa narrativa/problemática, uma imagem que a representasse, enfatizando "a relação que eles têm com a escola." Em diálogo com os alunos sobre o assunto, trazendo questóes como, por exemplo: "Por que estamos aqui, afinal? Por que esse desestimulo geral? E as faltas recorrentes, tanto de alunos como de professores? Por que comemoramos as saidas antecipadas da escola? Por que elas têm sido tão regulares?" Assim, a dinâmica da proposta desencadeou a possibilidade aos alunos e à professora de pensarem o que têm vivido na escola, como ela se organiza, o que estão fazendo na EJA e o que fazem de si mesmos nesse espaço.

A proposta era uma criação visual (em linguagem de livre escolha), a partir de tais questôes. Ela trazia inquietaçóes cotidianas que ganhavam forma, outra possibilidade de olhar, de embate, combate ou problematização. O objetivo era compartilhar, pensar junto, com o outro, no grupo, não na pretensão de encontrar uma soluçáo para todas as mazelas explicitadas nas classes escolares da EJA, mas sim com o intuito de sair do lugar de vítima el ou de permanecer somente nas queixas (em alusão ao trabalho artístico Coro

3 Exemplos de vídeos que foram discutidos nesse projeto de trabalho: "El empleo". Disponível em: <https:// www.youtube.com/watch?v=cxUuU1jwMgM> Acesso em: 12 fev. 2015), e "La Maison en Petits Cubes". Disponível em: <https://www.youtube.com/watch?v=O_2Sc8fD_Kc> Acesso em: 12 fev. 2015. 
de Queixas ${ }^{4}$, que foi apresentado como exemplo e referência para o exercício). Mesmo com estímulo e liberdade para a criaçáo em diferentes linguagens, as produçóes limitaram-se à tradicional folha de sulfite branco de formato A4, mais conhecida como folha de ofício. Diante da dificuldade dos estudantes em representar por meio de desenho - resistência internalizada pelos sujeitos ao longo de suas trajetórias de fracasso escolar, foram exploradas técnicas de colagem e esquemas com texto escrito ou esboço de ideias.

Para resultar nas produçóes finais propriamente ditas, a professora de artes necessitou desenvolver uma estratégia pedagógica capaz de contornar a frequência irregular, com grandes períodos de ausência à escola, de alguns estudantes da EJA. Constatou que a melhor forma de organizar o planejamento pedagógico com uma turma, cuja composiçẫo numérica é flutuante e está continuamente em movimento, seria individualizar os percursos de cada aluno, acompanhando-os individualmente em seus projetos. O trabalho individualizado exige do professor competência profissional para colocar em ação os múltiplos dispositivos de acompanhamento, reconhecendo a sua própria prática como um laboratório de pesquisa, ao aproximar-se corpo a corpo dos saberes e do acontecimento pedagógico. A seguir, seguem algumas das produçóes dos estudantes decorrentes desse olhar docente individualizado às trajetórias estudantis e da acolhida à ocasião inesperada ocorrida na aula de artes, como potência para o ofício de ensinar e aprender.

4 Coro de queixas de Teutônia-RS, organizado pelo artista finlandês Oliver Kochta-Kalleinen,com a colaboração da comunidade. Versão apresentada na $8^{a}$ Bienal do Mercosul, realizada em 2011, em Porto Alegre-RS. Disponível em: <https://www.youtube.com/watch?v=1Z28tiJuCWM> (acesso em: 11 fev. 2015). Esse projeto, já realizado em diversos contextos, conta com a participação de inúmeras pessoas e subverte o modo de ver ou perceber algo cotidiano: nossas queixas. Como poderíamos vê-las de outra maneira? Como eu ouço as queixas do outro? Temos as mesmas queixas? Assim, e com muitos outros questionamentos, os artistas Tellervo Kalleinen e Oliver Kochta-Kalleinen iniciam a criação de seu trabalho. Coletando as queixas por meio de encontros e workshops, organizam literalmente o cantar das queixas, em um coral que considera as especificidades e a cultura de cada local .Mais informaçóes sobre o projeto The Complaints Choir (O Coro de Queixas) podem ser acompanhadas por meio do site <http://www.complaintschoir.org/> (acesso em: 11 fev. 2015). 
Figura 1 - Produção do estudante A

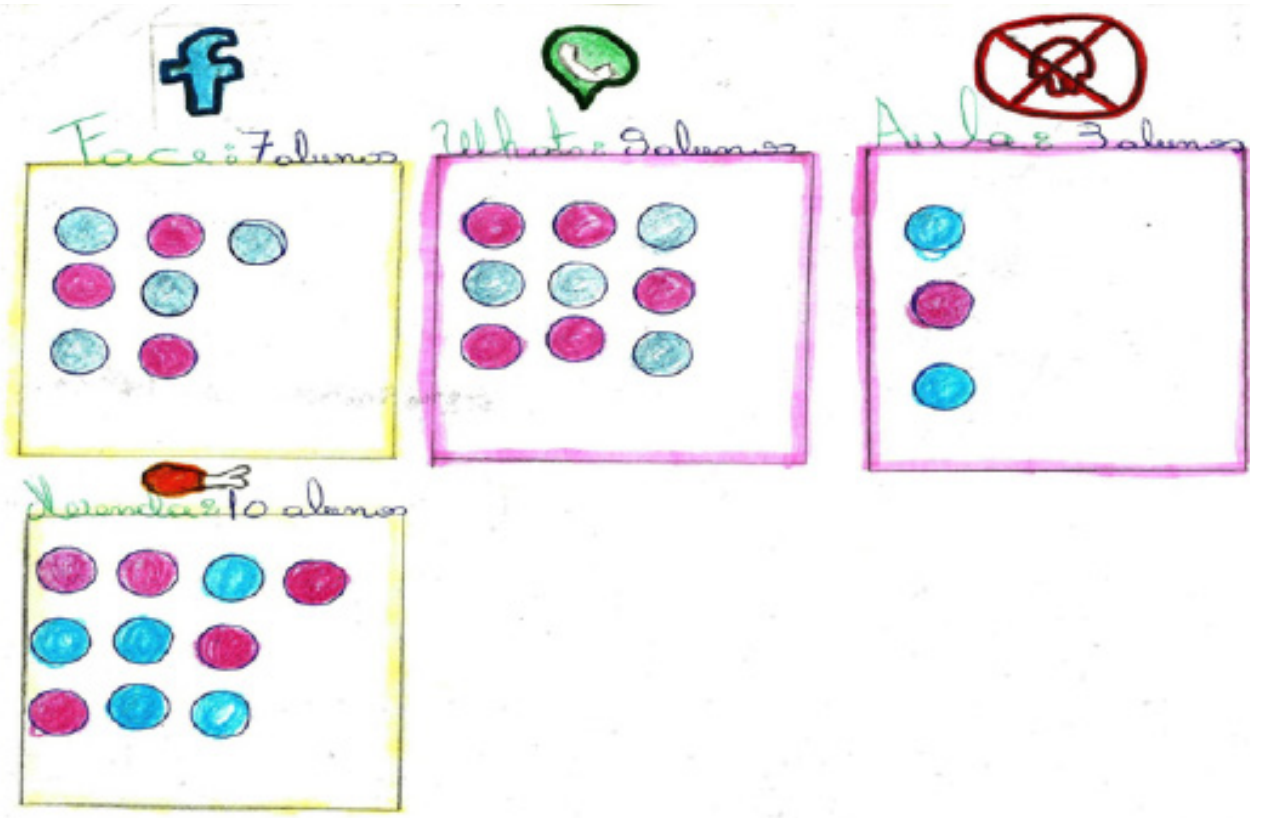

Fonte: Arquivo da autora.

Como em uma lista de interesses ou de presenças, o estudante A posiciona os demais colegas (representados por intermédio de círculos) nos seus lugares. Fica evidente a presença das tecnologias digitais na vida dos alunos, como acessório que também os acompanha no espaço escolar (veja figuração do acesso ao facebook e ao whatsapp). Merece destaque na representação do estudante A o relevante número de alunos dessa modalidade que valoriza a alimentação ou a merenda, espaço em que se localiza o maior número deles. A aula é representada como o lugar de menor presença ou interesse, além de sua forma figurativa ser de algo aparentemente proibido.

No trabalho que segue, também observamos a recorrência de produtos das novas tecnologias relacionada a drogas, representadas na imagem pelo desenho de um cigarro e relatadas na apresentaçáo oral do aluno. Ele diz que o que está em evidência seria um jogo (representado por meio do campo de futebol) das disciplinas (caracterizadas no desenho de livros, com as letras iniciais de cada área do conhecimento) versus as tecnologias e as drogas presentes na vida dos alunos. 
Figura 2 - Produção do estudante B

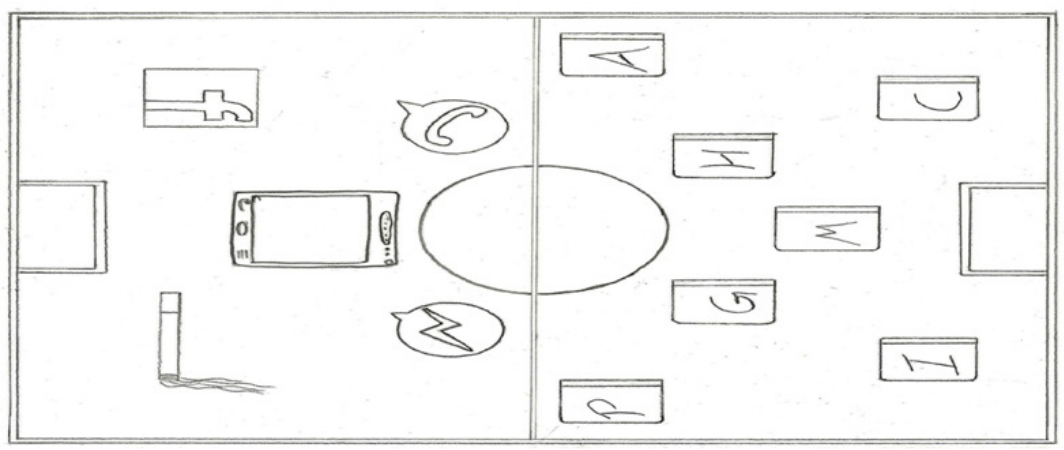

Fonte: Arquivo da autora.

Por meio de um relógio, representando o tempo vivido na escola, o estudante C, além de demonstrar a presença das tecnologias na vida dos alunos, traz novas cenas para pensar o espaço escolar. $\mathrm{Na}$ forma escrita, ele menciona, como parte do tempo escolar: "falta de atenção", "bate-papo dos/com os colegas", "maioria do tempo no banheiro", "estudar" (termo três vezes mencionado), "facebook", "whatsapp", "recreio ou saída".

Figura 3 - Produção do estudante C

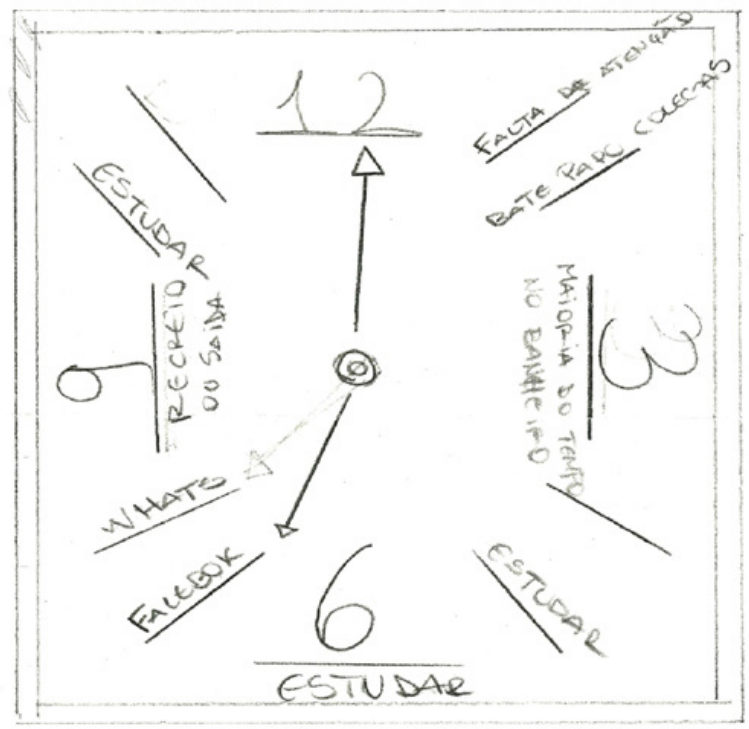

Fonte: Arquivo da autora. 
Ainda explorando cenas e pensamentos cotidianos acerca da problemática, nos interessa refletir a partir da produção da estudante $\mathrm{D}$, onde, em um esboço de ideias, precedendo a elaboração da produção artística, ela coloca o termo escola no centro e diz: "O tempo que eu passo na escola também é um tempo usado comigo, mas eu não gosto muito de vir para a escola." Além disso, no centro do trabalho, está escrito: "A escola tem regras."

O lado esquerdo da superfície é utilizado pela aluna para a classificação muito bom e o direito para a muito ruim, tentando explorar seus próprios pensamentos sobre o que discutíamos na realização da proposta. Para fins de conhecimento, reproduzimos o que ainda consta no trabalho. Na coluna do que seria muito bom, a estudante escreve: "- Hora da saída; - Porque é a hora que tenho para o meu aprendizado; - Às vezes me faz pensar, e isso é bom; - Hora do recreio." No outro lado, como muito ruim: “- Eu não gosto de seguir, mas tenho que segui-las (em relação às regras); - Hoje eu tenho aula = Que saco!!; - É cansativo porque eu não trabalho ainda e eu acho que os professores falam demais; - Às vezes eu fico irritada; - Às vezes as horas demoram para passar; Acho pensar muito cansativo às vezes."

Figura 4 - Produção da estudante D

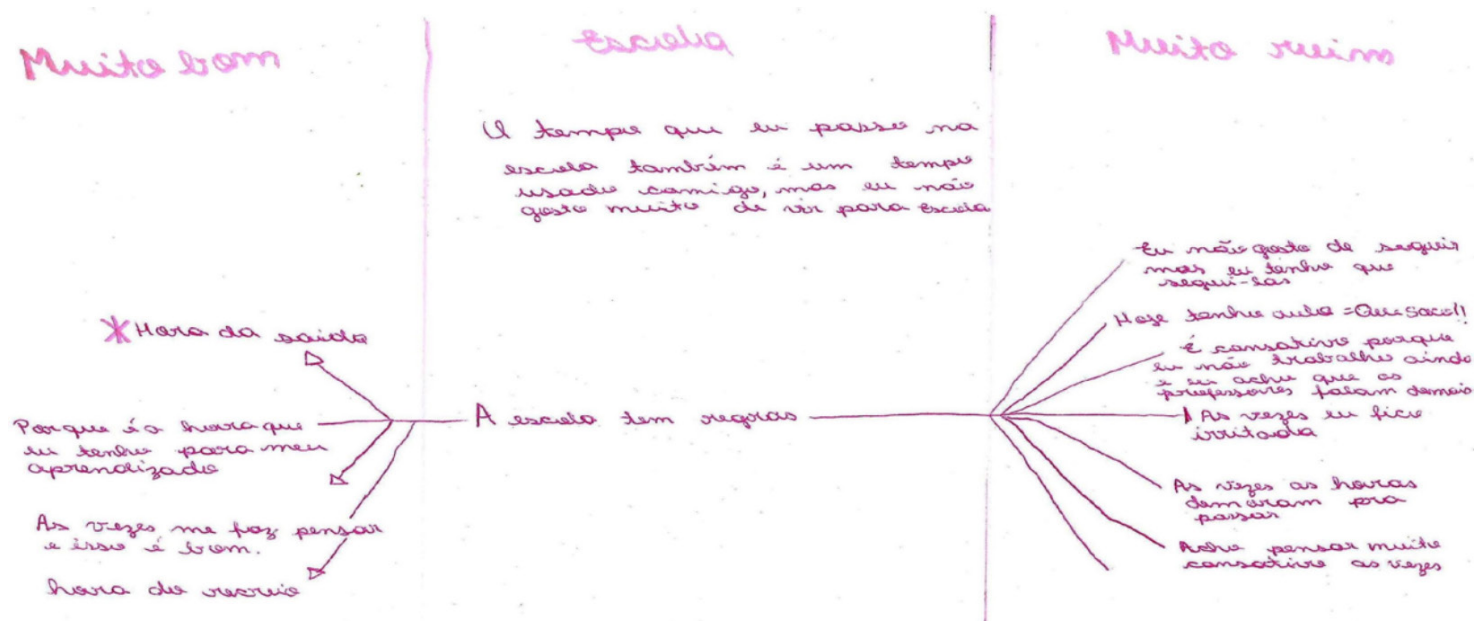

Fonte: Arquivo da autora.

Nesse último trabalho, percebem-se questóes cotidianas explicitadas com aparente sinceridade e o esforço do exercício de reflexão e síntese antecedendo a elaboração do trabalho artístico propriamente dito. Todas as etapas do trabalho são valorizadas, enfatizando-se a importância do processo. A concepção da ideia, a elaboração ou o planejamento, a própria execução, a apresentação e a 
discussão do trabalho com a professora, com os colegas próximos e com o grupo são igualmente valoradas.

No intento de aproximar o pensamento artístico das ocasióes cotidianas, estamos de acordo com o pensamento de Ana Mae Barbosa (2011), quando diz que:

A arte, como uma linguagem aguçadora dos sentidos, transmite significados que não podem ser transmitidos através de nenhum outro tipo de linguagem, tais como a discursiva e a científica. O descompromisso da arte com a rigidez dos julgamentos que se limitam a decidir o que é certo e errado estimula o comportamento exploratório, válvula propulsora do desejo de aprendizagem. Através da arte, é possível desenvolver a percepção e a imaginação para apreender a realidade do meio ambiente, desenvolver a capacidade crítica, permitindo analisar a realidade percebida e desenvolver a criatividade de maneira a mudar a realidade que foi analisada. (BARBOSA, 2011, p. 79).

A arte na escola ou a arte na EJA, ao posicionar-se atenta às produçóes contemporâneas, aberta à experimentação e criação a partir da vida cotidiana, compromete-se com a permeabilidade entre ética e estética anunciada por Hermann (2005), tornando a experiência estética uma via de acesso possível para a vida moral, como uma educação para a alteridade.

\section{Imagens da EJA: a formação inicial para a docência}

Gostariamos de poder tratar sobre como é dar aula para EJA? [...] Como é ser um professor de EJA? Como professores de crianças, temos os referenciais das nossas próprias experiências escolares, mas da experiência com adultos sabemos pouco, e a universidade também trata pouco sobre isso no currículo de nossos cursos. (Fala de acadêmicos em disciplina da graduação voltada à temática da EJA).

A apreciação oral destacada na citação anterior foi recorrente nas primeiras aulas da disciplina de Educação de Adultos: história e política, ministrada para distintos cursos de licenciatura, no caráter de disciplina eletiva, em uma universidade pública federal, durante o segundo semestre letivo de 2014 (2014/2). A disciplina, cuja carga horária total previa 30 horas/aula, abordou como conteúdo programático 
a contextualização histórica e política da modalidade de Educação de Jovens e Adultos, possibilitando o conhecimento dos documentos normativos e textos de autores considerados clássicos na área, resgatando, dessa forma, a memória histórica, política e pedagógica da educação de jovens e adultos no Brasil.

No encontro com os acadêmicos, uma das primeiras fragilidades da disciplina foi constatada em sua própria nomeação como educaçâo de adultos, omitindo a figura do jovem, atualmente bastante presente nos bancos escolares da EJA, sendo esse grupo etário o mais designado, ao longo das aulas, como de interesse por parte dos estudantes.

Ao considerar a similitude da experiência da formação inicial em nível superior com a modalidade de Educação de Jovens e Adultos, no que se refere à especificidade etária de seus demandantes, a professora teve como propósito primordial das aulas estabelecer uma relação pedagógica, cuja comunicação fosse ativada por meio de um "modelo orquestral" (WINKIN, 1998, p. 34 ), ou seja, como um ato coletivo próximo ao significado etimológico da palavra (communicare), como partilha ou comunhão de uma ideia ou notícia, ao invés de seu significado contemporâneo associado à transmissão entre um emissor e um receptor.

Desse modo, na experiência didática com os estudantes, a docente procurou estabelecer uma coreografia pedagógica moldada pelas suas inquietações, expectativas, comentários ou silenciamentos disparados em cada aula, produzindo um itinerário pedagógico rigoroso e, ao mesmo tempo, flexível, pautado na crença de que o ato pedagógico deve "[...] situar-se fora dos eixos, beneficiando-se da existência de referências" (MEIRIEU, 2008, p. 145).

Esse modo de coreografar o ato pedagógico e a relação com o conhecimento encaminhou a professora à escuta atenta e reflexiva de falas, como a destacada no início desta seção, resultando no planejamento de uma situação de aprendizagem em que os estudantes pudessem ter contato com a dinâmica pedagógica complexa, viva e pulsante de uma sala de aula da EJA, por meio do encontro com professores da educação básica nessa modalidade. $\mathrm{O}$ encontro foi possível a partir da presença de duas professoras na sala de aula da graduação, em uma das aulas, narrando, de modo bastante apaixonado e franco, os sabores e dissabores da prática pedagógica na educação de jovens e adultos em uma escola pública estadual de ensino do Rio Grande do Sul (RS), localizada na zona urbana de Porto Alegre (POA), nas etapas de escolarização correspondentes ao ensino fundamental.

Especificamente, o encontro com a professora de artes visuais das totalidades finais do ensino fundamental da EJA é objeto de apreciação e investigação, neste artigo. $\mathrm{Na}$ oportunidade do encontro, a turma de jovens futuros docentes pôde confrontar-se com a proposta artística narrada anteriormente, na qual a arte foi tratada como área de conhecimento que desafia o olhar ou "[...] leva o olhar a passear", 
como diz Larrosa (2002, p. 50), contribuindo para a formação dos estudantes da EJA e constituindo-se em uma metanarrativa (auto)formativa para os estudantes da graduação, quanto ao caráter genuinamente inédito do ato pedagógico, e, por isso, impossível de ser previsto antecipadamente, em sua totalidade.

A formação é uma viagem aberta, uma viagem que não pode estar antecipada, e uma viagem interior, uma viagem na qual alguém se deixa influenciar a si próprio, se deixa seduzir e solicitar por quem vai ao seu encontro, e na qual a questão é esse próprio alguém, a constituição desse próprio alguém, e a prova e desestabilização e eventual transformação desse próprio alguém. Por isso, a experiência formativa, da mesma maneira que a experiência estética, é uma chamada que não é transitiva. E, justamente, por isso, não suporta o imperativo, não pode nunca intimidar, não pode pretender dominar aquele que aprende, capturá-lo, apoderar-se dele. $\mathrm{O}$ que essa relaçáo interior produz não pode nunca estar previsto. (LARROSA, 2002, p. 53).

Perante a narrativa da professora, contextualizando as motivaçóes da imprevisibilidade do cotidiano que a levaram a reconfigurar a proposta pedagógica da aula de artes visuais, constituíram-se como pistas formativas acerca da prática pedagógica na EJA: o reconhecimento de que a potencialidade do ato pedagógico na educação de adultos está em falar com os sujeitos; a abertura da sala de aula para as suas narrativas; a acolhida com seriedade e respeito das suas inquietaçóes.

$\mathrm{Na}$ situação da visita pedagógica à turma da graduação, a professora da EJA, além de construir a oportunidade dos estudantes encontrarem-se por meio de seu relato com a sala de aula da EJA, acolheu os questionamentos deles. A metodologia do encontro tratada como aula-debate foi planejada e participada antecipadamente aos estudantes pela professora ministrante da disciplina, inspirando-se nos fundamentos da educação popular de Freire (1980):

Em lugar de professor, com tradições fortemente 'doadoras', o Coordenador de Debates. Em lugar de aulas discursivas, o diálogo. Em lugar de aluno, com tradiçóes passivas, o participante de grupo. Em lugar dos 'pontos' e de programas alienados, programação compacta, 'reduzida' e 'codificada' em unidades de aprendizado. (FREIRE, 1980, p. 103).

Uma questão enfaticamente problematizada pelos estudantes foi: quem são os estudantes da EJA que ocupam os bancos escolares das escolas públicas estaduais 
de ensino do RS? Perante a compreensão de que a EJA não pode ser tratada apenas em sua especificidade etária, mas sim em sua especificidade cultural (OLIVEIRA, 2001), interessava aos futuros professores saber as procedências escolares dos estudantes, seus contextos socioeconômicos, as motivaçóes e expectativas relacionadas à modalidade EJA. Em diálogo com a professora, puderam constatar a presença predominante de jovens nos bancos da EJA, constituindo-se como oportunidade para confirmar estudos feitos sobre o fenômeno de juvenilização da modalidade, a partir de Dayrell (2011) e Brunel (2008), entre outros autores.

Como decorrência náo esperada da aula-debate, os estudantes puderam problematizar as suas representaçóes sociais acerca da EJA. Frequentemente, traziam às aulas as narrativas hegemônicas do ideário social da EJA como "escolarização tapa furo" ou "repositório dos estudantes indisciplinados e fracassados", descrevendo o professor da EJA como desmotivado e o aluno jovem como problema. Confrontar essas narrativas negativas tornou-se importante para que pudessem ter uma atitude de positividade e de comprometimento com as funçóes da EJA, descritas no Parecer Nacional do CNE/CEB 11/2000, a saber: qualificadora como função permanente que descreve o próprio sentido da EJA, reparadora e equalizadora, no sentido de restauração de um direito negado, bem como do reconhecimento da igualdade ontológica de todo ser humano (BRASIL, 2000).

$\mathrm{O}$ confronto com a generalização contida nessas narrativas foi ainda mais marcante para os acadêmicos, com a apresentação dos produtos (fotografia dos trabalhos artísticos dos alunos) resultantes da situação pedagógica anunciada pela professora, na disciplina de artes visuais. Os estudantes universitários mostraramse bastante sensibilizados e afetados com as leituras dos alunos da EJA, a partir da produção de imagens, a respeito do desencontro entre as práticas pedagógicas da escola e os interesses do corpo estudantil jovem e adulto.

O descompasso entre a cultura escolar e as culturas juvenis ficou bastante evidente para os licenciandos, nas representaçóes dos estudantes da EJA, no sentido de que suas motivaçóes para ir à escola não dialogam com a busca pelo conhecimento, uma vez que a escola se comporta de modo alheio às suas culturas juvenis. Para Dayrell (2011), acolher às culturas juvenis significa reconhecer que não existe apenas uma juventude, mas juventudes no plural, enfatizando, assim, a diversidade de modos de ser jovem. $\mathrm{O}$ autor afirma que levar em conta os jovens como sujeitos significa repensar a escola, sua organização curricular e suas práticas a partir de uma nova pauta de questóes:

Como fazer da escola e das nossas práticas pedagógicas educativas um momento de humanizaçáo? [...] Como considerar o protagonismo juvenil, considerando os 
jovens como interlocutores válidos, capazes de opinar nos projetos que lhes dizem respeito? [...] Como despertar e incentivar o desejo pelo saber, dialogando com os interesses e necessidades dos jovens? Como incentivar as diferentes linguagens culturais, possibilitando a expressão autônoma das culturas juvenis? (DAYRELL, 2011, p. 66).

A situação pedagógica em foco abriu caminhos para a reflexão sobre a delicadeza e a sutileza do ato pedagógico. As aparentes relaçóes de confiança entre a professora de artes e os estudantes, oportunizando a abertura para que eles se colocassem de maneira sincera, extremamente crítica, sem receios de articular a criatividade com a ironia, foram aspectos merecedores de atenção e, se não respondem todas as questóes de Dayrell (2011), fornecem significativos indícios para pensar a respeito delas.

Em suma, a mencionada coreografia pedagógica, ao conceber a formaçáo inicial como o espaço para pesquisar, construir, analisar, confrontar com os colegas e com os profissionais da educação as situaçóes de aprendizagem na EJA, possibilitou aos futuros docentes que refletissem acerca da complexidade de reconhecer a condição de náo crianças, de sujeitos excluídos da escola e de membros de distintos grupos sociais, como características que tratam da identidade dos sujeitos da EJA (OLIVEIRA, 2001).

\section{Ressonâncias da articulação entre a universidade e a escola de educação básica}

Ao propiciar o encontro entre a universidade e a escola, buscamos sustentar que se formar professor da EJA não pode ser uma prática que conduza à imitaçáo de modelos ou ao aprendizado prévio de rotinas e fórmulas. Requer uma relação interior com o saber, de modo que o aprender forma ou transforma o sujeito:

$\mathrm{Na}$ formação humanística, como na experiência estética, a relação com a matéria de estudo é de tal natureza que, nela, alguém se volta para si mesmo, alguém é levado para si mesmo. E isso não é feito por imitação, mas por algo assim como ressonância. (LARROSA, 2010, p. 52).

Nesse sentido, as considerações em caráter de fechamento, que trazemos nesta seção, são tratadas como ressonâncias dos distintos itinerários formativos mobilizados por meio da situação pedagógica narrada e refletida neste estudo. 
Certamente, os ecos ressonantes para cada um dos sujeitos envolvidos náo podem ser recuperados pelas autoras. Retomamos aquilo que reverbera em nós, reconhecendo-nos, igualmente, em processo formativo constante e intimamente afetadas pelos movimentos decorrentes dessa experiência. Portanto, são repercussóes ou consideraçóes oriundas desse percurso formativo:

- O encontro dos saberes profissionais das professoras da EJA e da Educação Superior suscita-nos a reflexão sobre a importância de reconhecer que a ação pedagógica independe do nivel de ensino e resguarda a natureza do ofício de mestre: "É sempre o mesmo ofício: um ofício que associa, com um único gesto profissional, o saber e o acompanhamento." (MEIRIEU, 2006, p. 21). Em qualquer faixa etária, em qualquer nível, etapa ou modalidade de ensino, o ato de aprender requer uma escuta atenta e compreensiva do mestre, sendo que são nas situaçóes-problema ou nos anúncios das necessidades do cotidiano que o docente tem a possibilidade de exercer melhor essa característica do seu ofício. Assim, a autêntica ação pedagógica instiga simultaneamente o caráter desafiador do desconhecido e a segurança do acompanhamento necessário.

Quanto aos tempos de vida do jovem e do adulto, o legado da educação popular, iniciado com Paulo Freire, continua atual, como subsídio teóricometodológico para a açáo pedagógica na EJA.

- Com relação às especificidades da ação pedagógica na EJA, confrontar-se com diferentes temporalidades e trajetórias humanas pressupóe a abertura docente à resistência do outro, permitindo aos estudantes afirmarem sua alteridade $e$ responsabilizarem-se como protagonistas de seu próprio percurso formativo:

Reconhecendo que a educação é, em muitos casos, um processo em que se realiza o projeto que o educador tem sobre o educando, também é o lugar em que o educando resiste a esse projeto, afirmando a sua alteridade, afirmandose como alguém que não se acomoda aos projetos que possamos ter sobre ele, como alguém que não aceita a medida de nosso saber e de nosso poder, como alguém que coloca em questáo o modo como nós definimos o que ele é, o que quer e do que necessita, como alguém que não se deixa reduzir aos nossos objetivos e que não se submete a nossas técnicas. (LARROSA, 2002, p. 15).

$\mathrm{Na}$ EJA, a resistência do aluno, se compreendida como ato de inquietude pedagógica a ser participado com os sujeitos, pode auxiliar a recompor os seus 
itinerários ou percursos escolares distanciados do ato de aprender pelas próprias reminiscências das suas multifacetadas trajetórias escolares e humanas.

Essas resistências devem servir para confrontar as imagens que trazemos sobre a infância como tempo de semeadura ou de modelagem para a vida jovem e adulta, isso é, como tempos lineares, contínuos e ininterruptos. Essas metáforas auxiliaram a construir um ideário de homogeneidade e linearidade nas trajetórias escolares, portanto, não servem mais para descrever as múltiplas e distintas trajetórias que se justapóem em uma sala da EJA. Essas imagens da docência, como diz Arroyo (2012, p. 35), estão "quebradas", no sentido de que estáo equivocadas, pois não traduzem a realidade dos cotidianos escolares. Logo, faz parte da docência recompor as imagens e entender nas resistências dos estudantes e na descontinuidade de seus percursos escolares a forma de comunicarem que a escola está distante das culturas juvenis, a exemplo das representaçóes dos sujeitos da EJA apresentadas na aula de artes visuais.

O processo de formaçáo inicial, por sua vez, ao propiciar aos estudantes da graduaçáo o contato com essas imagens quebradas dos tempos de vida humanos demonstra o seu comprometimento ético em romper com a lógica formativa da idealização do ofício de ensinar, tradição suplantada historicamente na formação em educação, deflagrada por Arroyo na seguinte assertiva: "Não nos prepararam para conviver com imagens quebradas." (ARROYO, 2012, p. 38).

- A complexidade da ação pedagógica na EJA envolve reconhecer que existe uma narrativa coletiva a respeito das representaçóes dos principais desafios da modalidade descritos por diferentes estudos em continua atualização, sendo que a forma de orquestrar essas narrativas de cunho geral deve ser local ou localizada em cada contexto especifico.

Não é nova a situação anunciada por distintos estudos da marginalização das políticas públicas na EJA e de suas múltiplas mazelas sociais, políticas, pedagógicas e econômicas. Essa narrativa de cunho geral, todavia, náo pode obstacularizar o enfrentamento das situaçóes nos cotidianos. Não encontraremos soluçóes $a$ priori do envolvimento sério e comprometido com os contextos, repropondo continuamente uma ética do cotidiano. No enfrentamento com a infrequência dos estudantes da EJA nessa escola, por exemplo, a professora de artes percebeu que o modo mais potente seria individualizar seus percursos, de modo que cada estudante construiu seu projeto de artes, de maneira individual, sem necessidade de estar atuando, em momento síncrono, nas mesmas atividades ou situaçóes de aprendizagem dos demais.

Considerando a complexidade da ação pedagógica na EJA, descrita pela sua história de ausências e lacunas e pela sua emergência atual como acolhedora da diversidade, a formaçáo do educador da EJA precisa ir além da bagagem de 
conhecimentos a respeito dos conteúdos e técnicas didáticas e deve estabelecer a possibilidade de reconhecer no campo da estética um dispositivo de conexáo ao compromisso da EJA com os processos educativos mais amplos relacionados à formação humana.

A ciência, sustentada na memória cartesiana, tradicionalmente, teve dificuldade em unir emoção e razão como elementos interdependentes. A arte, historicamente, tem provocado as ciências a romperem com esses dualismos, despertando uma consciência política sobre as táticas do fazer e do intervir, por meio da relação pedagógica:

A consciência política de que precisamos integrar arte, educação e cultura nos faz perceber que também é preciso criar uma proposta que priorize as necessidades do nosso povo, que atenda, primeiramente, as classes populares que são a maioria do contingente que frequenta nossas escolas. (MEIRA, 2001, p. 112).

Acolher a estética como dispositivo da ação pedagógica na EJA significa reconhecer a incerteza como característica intrínseca ao ato; significa despojarmo-nos de uma prepotência, a prepotência ilusória de que podemos controlar os acontecimentos pedagógicos e as trajetórias formativas dos sujeitos. Implica compreender que as possibilidades estéticas e comunicacionais, políticas e éticas de vivenciar o acontecimento pedagógico são infinitas e singulares. As palavras de Meirieu (2006) traduzem nossas convicçóes acerca da ação pedagógica na EJA:

Jamais devemos perder de vista que o acontecimento pedagógico não pode ser programado por ninguém. Podemos fazer de tudo para que ele ocorra, empenharnos para torná-lo plausível... Mas, felizmente ele será sempre excepcional. Embora bastante previsível, ele não deixa de ser, quando ocorre, inimaginável. (MEIRIEU, 2006, p. 47).

- A história que articula os saberes da universidade e da escola básica precisa ser reescrita. A polarização e a hierarquização entre esses saberes, consecutivamente, como antagônicos e de maior ou menor valia, fragiliza a relação pedagógica com a docência. Reforça no professor de escola o lugar do espectador do coral das queixas e a imagem de que estaria nas mãos da universidade ou dos gestores das políticas públicas salvar a EJA. 
Em toda ocasião pedagógica em que o docente se mobiliza seriamente ele auxilia a salvar a EJA, pois constrói a possibilidade de subverter as narrativas hegemônicas. As produçóes artísticas dos estudantes da EJA não solucionarão os desafios macropolíticos e, nem mesmo, todos os problemas do seu próprio contexto escolar, mas salvam a EJA da reprodução de uma narrativa pedagógica de conformismo e de reprodução dele. Ao proporem outra forma de olhar os desafios cotidianos, elas provocaram a inquietude dos sujeitos que estiveram envolvidos na experiência, permitindo-lhes ver e relacionar-se com a EJA por outros ângulos e pelo seu próprio viés, e não apenas por aquele supostamente esperado pelos docentes.

\section{Referências}

ARROYO, Miguel. Educação de Jovens e Adultos: um campo de direitos e de responsabilidades públicas. In: SOARES, Leôncio; GIOVANETTI, Maria Amélia; GOMES, Nilma Lino (Org.) Diálogos na educaçáo de jovens e adultos. 4. ed. Belo Horizonte: Autêntica, 2011. p. 19-52.

ARROYO, Miguel. Imagens quebradas. Trajetórias e tempos de alunos e mestres. 7. ed. Rio de Janeiro: Vozes, 2012. 405 p.

BARBOSA, Ana Mae. Educaçáo para as Artes Visuais: do MAC USP ao Balanço das Águas. In: ARANHA, Carmem S. G; CANTON, Katia. (Org.). Espaços da mediaçáo. São Paulo: PGEHA/Museu de Arte Contemporânea da Universidade de São Paulo, 2011. p. 63-83.

BRASIL. Conselho Nacional de Educação. Câmara de Educação Básica. Diretrizes Curriculares Nacionais para a Educaçáo de Jovens e Adultos. Parecer n. 11/2000, de 10 de maio de 2000. Brasília, DF, 2000.

BRUNEL, Carmen. Jovens cada vez mais jovens na educaçáo de jovens e adultos. 2. ed. Porto Alegre: Mediação, 2008. 91 p.

DAYRELL, Juarez Tarcísio. A juventude e a Educação de Jovens e Adultos: reflexôes iniciais - novos sujeitos. In: SOARES, Leôncio; GIOVANETTI, Maria Amélia; GOMES, Nilma Lino (Org.). Diálogos na educaçáo de jovens e adultos. 4. ed. Belo Horizonte: Autêntica, 2011.p. 53-68.

FREIRE, Paulo. A importância do ato de ler: em três artigos que se completam. 23. ed. São Paulo: Autores Associados, Cortez, 1989. 49 p. 
FREIRE, Paulo. Conscientizaçáo: teoria e prática da libertação. São Paulo: Moraes, 1980. $102 \mathrm{p}$.

HERMANN, Nadja. Ética e estética: a relação quase esquecida. Porto Alegre: EDIPUCRS, 2005, 119 p.

LARROSA, Jorge. Pedagogia Profana. Danças, piruetas e mascarados. Tradução de Alfredo Veiga-Neto. 5. ed. Belo Horizonte: Autêntica, 2010, 208p.

MEIRA, Marly Ribeiro. Educação Estética, arte e cultura do cotidiano. In: PILLAR, Analice Dutra (Org.) A educaçáo do olhar no ensino das artes. 6. ed. Porto Alegre: Mediação, 2011, p. 101-120.

MEIRIEU, Philippe. Cartas a um jovem professor. Porto Alegre: Artmed, 2006. 93 p. MEIRIEU, Philippe. A pedagogia entre o dizer e o fazer A coragem de começar. Porto Alegre: Artmed, 2008. 302 p.

OLIVEIRA, Marta Kohl de. Jovens e Adultos como sujeitos de conhecimento e aprendizagem. In: RIBEIRO, Vera Masagão (Org.) Educaçáo de Jovens e Adultos Novos leitores, novas leituras. 3. ed. São Paulo: Mercado das Letras, 2008. p. 15-44.

SOARES, Leôncio. As políticas de EJA e as necessidades dos jovens e adultos. In: RIBEIRO, Vera Masagão (Org.) Educaçáo de Jovens e Adultos Novos leitores, novas leituras. 3. ed. São Paulo: Mercado das Letras, 2008. p. 201-224.

WINKIN, Yves. A nova comunicaçáo. Da teoria ao trabalho de campo. Tradução de Roberto Leal Ferreira. Campinas: Papirus, 1998. 216 p. 